Discussion Paper No. 10-039

\title{
Innovation, Competition and Incentives for R\&D
}

Martin Wörter, Christian Rammer, and Spyros Arvanitis

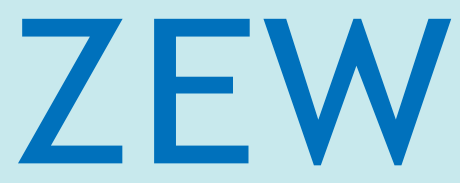

Zentrum für Europäische Wirtschaftsforschung $\mathrm{GmbH}$

Centre for European

Economic Research 
Discussion Paper No. 10-039

\title{
Innovation, Competition and Incentives for R\&D
}

\author{
Martin Wörter, Christian Rammer, \\ and Spyros Arvanitis
}

Download this ZEW Discussion Paper from our ftp server:

ftp://ftp.zew.de/pub/zew-docs/dp/dp10039.pdf

Die Discussion Papers dienen einer möglichst schnellen Verbreitung von neueren Forschungsarbeiten des ZEW. Die Beiträge liegen in alleiniger Verantwortung der Autoren und stellen nicht notwendigerweise die Meinung des ZEW dar.

Discussion Papers are intended to make results of ZEW research promptly available to other economists in order to encourage discussion and suggestions for revisions. The authors are solely responsible for the contents which do not necessarily represent the opinion of the ZEW. 


\section{Non-technical Summary}

Exploring the links between the type of innovation and the type of competition is essential to understand the mutual impacts of competition policy and innovation policy. This is of particular importance for countries which rely on innovation as a competitive advantage such as Germany and Switzerland, which are the focus countries of the empirical analysis.

The paper investigates three research questions: Is there a relationship between past innovation output and the type of competition? Do product and process innovation exert different impacts on the type of competition in the sales markets? Does the type of competition affect incentives for future investment in innovative activities? Following the theoretical findings of Vives (2008) who states that the degree of product substitutability and the extent of fixed costs -as two important characteristics of competition- are both positively correlated with process innovation effort and negatively correlated with product innovation effort, we analyse the links between past and future innovation efforts and these two types of competition.

The empirical analyses rest on firm-level data from Germany and Switzerland. We use firms' own assessments on the degree to which their products are substitutable by competitors' products and the speed of product obsolescence (which should be negatively correlated to the extent of fixed costs) as measures for competition. We find for both countries that innovation output in t-1 as measured by the sales share of innovative products is positively related to the degree of product obsolescence in $t$, and negatively to the degree of substitutability in $t$ in both countries. This result indicates that it is product innovation that drives technology competition which points to the fact that a lack of product innovations urges firms into substitution competition. We find different results by country in terms of process innovation: Cost reductions by German firms tend to increase product obsolescence and reduce substitutability, indicating that cost saving process innovation is a strategy to improve price competitiveness both in markets with rapid technological aging or with a high degree of product substitution. For Switzerland, we find a negative effect of process innovation on product obsolescence, i.e. cost savings are primarily used to lower product prices in mature markets with low technological dynamics.

For the effect of the type of competition on future innovation effort, we find different results for the two competition variables. While great product obsolescence provided positive incentives for future R\&D investments (which are primarily oriented to product innovations), great 
substitutability provided negative incentives for $R \& D$ investment. Thus, we found a 'vicious circle' for product substitutability indicating that firms in such markets are under increasing cost pressure and can to a much lesser extent afford innovative activities that lead to product innovations. In contrast, a high degree of product obsolescence leads to greater R\&D investments in the future period. Our results indicate that innovation and competition tend to reinforce each other (positively or negatively), and it is difficult for firms to change a chosen path. 


\section{Das Wichtigste in Kürze}

Die Analyse der Verbindung zwischen der Innovationstätigkeit von Unternehmen und der Form des Wettbewerbs, dem sich die Unternehmen gegenübersehen, ist unverzichtbar für das Verständnis der Wechselwirkungen zwischen Wettbewerbs- und Innovationspolitik. Dies gilt ganz besonders für Länder, deren Wettbewerbsvorteil auf einer hohen Innovationsfähigkeit beruht, wie z.B. Deutschland und die Schweiz.

In diesem Aufsatz werden für diese beiden Länder drei Forschungsfragen empirisch untersucht: Gibt es einen Zusammenhang zwischen den Innovationsergebnissen von Unternehmen aus früheren Perioden und der aktuellen Wettbewerbsform? Üben Produkt- und Prozessinnovationen unterschiedliche Effekte auf die Wettbewerbsform aus? Hat die Wettbewerbsform einen Einfluss auf künftige Investitionen in Innovationsaktivitäten? Aufbauend auf den theoretischen Analysen von Vives (2008), der festgestellt hat, dass das Ausmaß der Substituierbarkeit von Produkten und die Höhe der Fixkosten - die beide wesentliche Merkmale des Wettbewerbs im Absatzmarkt sind - jeweils positiv mit Prozessinnovationen, jedoch negativ mit Produktinnovationen korreliert, wird der Zusammenhang zwischen früheren und künftigen Innovationsanstrengungen und diesen beiden Aspekten des Wettbewerbs untersucht.

Die empirischen Analysen beruhen auf Unternehmenspaneldaten aus Deutschland und der Schweiz. Die Wettbewerbsform wird über die direkte Einschätzung der Unternehmen zum Grad der Substituierbarkeit ihrer Produkte durch Konkurrenzprodukte sowie zur Schnelligkeit des Alterns der eigenen Produkte (die negativ mit dem Ausmaß von Fixkosten korreliert sein sollte) gemessen. Für beide Länder zeigt sich, dass der Produktinnovationserfolg in der Vorperiode, gemessen über den Umsatzanteil neuer Produkte, positiv auf einen durch rasches $\mathrm{Al}$ tern der Produkte geprägten Wettbewerb, jedoch negativ auf einen Substitutionswettbewerb in der aktuellen Periode wirkt. Dieses Ergebnis deutet an, dass Produktinnovationen den Technologiewettbewerb anheizen, während zu geringe Produktinnovationsaktivitäten die Unternehmen in einen Substitutionswettbewerb drängen. Für den Einfluss von vorangegangenen Prozessinnovationsaktivitäten zeigen sich dagegen je nach Land unterschiedliche Resultate. Die Einführung von kostensenkenden Prozessinnovationen geht in Deutschland mit einem verschärften Technologiewettbewerb (d.h. einem rascheren Altern der Produkte) und einem geringeren Substitutionswettbewerb einher, was auf die Rolle von Kostenreduktionen als eine Strategie zur Verbesserung der preislichen Wettbewerbsfähigkeit sowohl in Märkten mit raschen technologischen Wandel als auch zur Vermeidung von Substitutionswettbewerb hin- 
deutet. Für die Schweiz zeigt sich dagegen ein negativer Effekt kostensenkender Prozessinnovationen auf einen durch rasches Altern von Produkten gekennzeichneten Wettbewerb, d.h. Kosteneinsparungen werden vor allem in reiferen Märkten mit geringerer technologischer Dynamik verfolgt.

Der Einfluss des Wettbewerbs auf die künftigen Innovationsaktivitäten - gemessen als FuEAufwendungen, die tendenziell auf Produktinnovationen abzielen - unterscheidet sich je nach Wettbewerbsform. Märkte mit raschem Altern der Produkte bieten positive Anreize für eine Ausweitung der FuE-Ausgaben, während von einem intensiven Substitutionswettbewerb negative Anreize ausgehen. Folglich zeigt sich ein sich selbst verstärkender Prozess zwischen Innovation und Wettbewerb. Die geringen Preisspielräume bei intensivem Substitutionswettbewerb schränken die Möglichkeiten künftiger FuE-Aktivitäten und damit von Produktinnovationen ein, was wiederum den Substitutionswettbewerb weiter verstärkt. Umgekehrt sind Unternehmen, die in Märkten mit raschem Altern der Produkte tätig sind, eher in der Lage, höhere FuE-Aufwendungen zu realisieren, was künftige Produktinnovationserfolge und somit die Festigung dieser Wettbewerbsform befördern kann. Dies bedeutet, dass es für Unternehmen schwierig ist, einen einmal eingeschlagenen Pfad der Innovationsausrichtung und der Wettbewerbsform zu verlassen. 


\title{
Innovation, Competition and Incentives for $\mathbf{R} \& D$
}

\author{
Martin Wörter ${ }^{1}$, Christian Rammer ${ }^{2}$, and Spyros Arvanitis ${ }^{3}$
}

May 2010

\begin{abstract}
This paper analyses the relationship between past innovation output, competition, and future innovation input in a dynamic econometric setting. We distinguish two dimensions of competition that correspond to the concepts of product substitutability and entry barriers due to fixed costs. Based on firm-level panel data for Germany and Switzerland we obtain consistent results for both countries. Innovation output in $\mathrm{t}-1$ as measured by the sales share of innovative products is positively related to the degree of product obsolescence in $t$, and negatively to the degree of substitutability in $t$ in both countries. Further, we find that rapid product obsolescence provides positive incentives for higher - primarily product-oriented $-\mathrm{R} \& \mathrm{D}$ investments in $t+1$, while high substitutability exerts negative incentives for future $R \& D$ investment.
\end{abstract}

Keywords: Innovation, R\&D, Competition

JEL-Classification: $\mathrm{O} 3$

Acknowledgements: We thank the participants of the ZEW Research Seminar for fruitful comments and suggestions.

\footnotetext{
${ }^{1}$ ETH Zurich, Swiss Economic Institute KOF, CH-8092 Zurich, woerter@kof.ethz.ch (corresponding author).

${ }^{2}$ Centre for European Economic Research (ZEW), Department of Industrial Economics and International Management, L 7, 1 - D-68161 Mannheim; rammer@zew.de

${ }^{3}$ ETH Zurich, Swiss Economic Institute KOF, CH-8092 Zurich, arvanitis@kof.ethz.ch.
} 


\section{Introduction}

At the latest since the writings of Schumpeter (1942) it is expected that innovation activities and market competition are related. Economic literature so far is inconclusive about the relationship between innovation and competition and we know even less about the dynamics of innovation output, competition and innovation input in a future period. It is the goal of this paper to investigate these dynamics, i.e. to look how past innovation output relates to the current level of competition and how competition in turn, impacts future R\&D expenditures.

Exploring the links between the type of innovation and the type of competition is essential to understand the mutual impacts of competition policy and innovation policy. This is of particular importance for countries which rely on innovation as a competitive advantage (such as Germany and Switzerland, the focus countries of our empirical analysis).

More concretely we investigate the following research questions: Is there a relationship between past innovation output and the type of competition? Do product and process innovation exert different impacts on the type of competition in the sales markets? Does the type of competition affect incentives for future investment in innovative activities? A key feature of our paper is to distinguish two types of competition, i.e. product substitution competition and technology competition (referring to the speed of product obsolesce).

In order to answer these questions we mainly followed the theoretical findings of Vives (2008). Vives (2008) essentially stated that the degree of product substitutability - as a type of competition - is positively correlated with process innovation effort and negatively correlated with product innovation effort; he also stated that the extent of fixed costs is positively correlated with process innovation effort and negatively correlated with product innovation effort. Given that fixed costs are negatively correlated with product obsolescence (as a further type of competition), we would expect a negative relationship between process innovation and product obsolescence and a positive relationship between product innovation and product obsolescence.

Based on firm-level panel data for Germany and Switzerland we find for both countries that innovation output in t-1 as measured by the sales share of innovative products is positively related to the degree of product obsolescence in t, and negatively to the degree of substitutability in $\mathrm{t}$ in both countries. The first result indicates that it is product innovation that drives 
technology competition. The latter result points to the fact that a lack of product innovations urges firms into substitution competition, and product innovations are a way out of this type of competition. We find different results by country in terms of process innovation: Cost reductions by German firms tend to increase product obsolescence and reduce substitutability, indicating that cost saving process innovation is a strategy to improve price competitiveness both in markets with rapid technological aging or with a high degree of product substitution. For Switzerland, we find a negative effect of process innovation on product obsolescence, i.e. cost savings are primarily used to lower product prices in mature markets with low technological dynamics.

Knowing that innovation output is an important factor for explaining the type of competition, we further wanted to know how competition relates to future R\&D investments. Here, we found again different results for the two competition variables. While great product obsolescence provided positive incentives for future $R \& D$ investments (which are primarily oriented to product innovations), great substitutability provided negative incentives for $R \& D$ investment. Thus, we found a 'vicious circle' for product substitutability, i.e. few innovation activities in $\mathrm{t}-1$ and low incentives for $\mathrm{R} \& \mathrm{D}$ investments in $\mathrm{t}+1$. That means that firms in such markets are under increasing cost pressure and they can to a much lesser extent afford innovative activities that lead to product innovations. In the medium term such firms are likely to outsource their production to countries with lower prices for production factors than Switzerland and Germany can offer. We found a completely different picture for competition referring to the rate of product obsolescence. This type of competition is nurtured through innovation activities on the product level and it also leads to greater R\&D investments in the future period. Our results indicate that innovation and competition tend to reinforce each other (positively or negatively), and it is difficult for firms to change a chosen path.

The paper is organized as follows. We introduce the theoretical notions in section two. Section three presents empirical issues, like the data base for both countries, the definitions of competition, innovation, and other variables, and the econometric procedures. Section four shows the results of this investigation and section five concludes.

\section{Theoretical Notions}

The theoretical question to be investigated is whether competitive pressure fosters innovation and vice versa. There is by now a large body of theoretical work that can be traced back 
to Schumpeter (1934, 1942) and Arrow (1962) with regard to the impact of competition on innovation effort. The effect of competition on innovation has been a controversial topic in economics since Schumpeter confronted economists with the theory that the perfectly competitive market is not necessarily the most effective mode of coordinating innovative activities. Recent theoretical work is related either to industrial organisation, endogenous growth theory or agency theory (see Gilbert, 2006, and Vives, 2008, for a discussion of the main theoretical approaches). ${ }^{4}$

Leading models of process innovation that are often used as reference of the theoretical discussion are the models of Dasgupta and Stiglitz (1980) and Spence (1984) based on constantelasticity functional forms. These authors find that increased competition, as measured by the number of firms in the market, reduces cost reduction expenditure per firm, i.e. the effort for process innovation at the firm level. Similar conclusions are found also in the first generation of Schumpeterian growth models (see, e.g., Aghion and Howitt, 1992). In these models competition in form of innovative newcomers decreases the monopolistic rents of successful innovators among the incumbent firms, thus their incentives for further innovation.

The model of Dixit and Stiglitz (1977) is also based on constant-elasticity specification and serves as reference model for product innovation, especially for endogenous growth models with product differentiation (e.g., Grossman and Helpman, 1989). Such models typically predict that more intense product market competition, as measured by an increase in the substitutability between differentiated products, reduces post-entry rents, and therefore the incentives for product innovation.

Most theoretical works predict that innovation should decline with competition. Of course there exists also the opposite direction, namely approaches that postulate a positive effect of competition on innovation, for example, the replacement effect in Arrow (1962) and the efficiency effects in Gilbert and Newbury (1982) and Reinganum (1983). ${ }^{5}$ Particularly, Schumpeterian growth models of the second generation try to incorporate positive competition effects on innovation (see Aghion and Howitt, 2005, for a survey of this literature). In Aghion

\footnotetext{
${ }^{4}$ See also Gaffard (2008) for a discussion of theoretical literature on this topic from an evolutionary point of view (especially section 5.2 "Competition and Innovation").

${ }^{5}$ See also Schmutzler (2010) for a further theoretical clarification of the conditions under which the effects of increasing competition on cost-reducing investment (process innovation) can be positive, negative or nonmonotone.
} 
et al. (2005) the first generation base model is expanded in a way that innovation incentives of the incumbent firms do not exclusively depend on post-innovation profits but on the difference between pre-innovation and post-innovation profits. In this case more intensive competition leads to more innovation when the introduction of the newcomer innovation decreases pre-innovation profits of the incumbent firms stronger than their post-innovation profits. Under such conditions innovation projects could become profitable because they could help to keep newcomers out of the market (positive “escape-competition” effect). This would be rather the case when competitors have similar cost structures. When cost structures strongly differ, more competition would decrease the innovation incentives of firms having unfavourable cost structures (negative "Schumpeterian” effect). These two opposite effect can be combined in an inverse U-shaped relationship between innovation and competition. Strictly is this relationship formulated for process innovation but implicitly holds also for product innovation.

The above short discussion has shown that it is still an open question in theoretical work whether negative effects of competition on innovation in the tradition of Schumpeter are stronger than positive effects in the line of Arrow.

For our empirical study an important issue is the definition and measurement of competition. As a conceptual guide for our work we rely on a recent paper by Vives (2008). His main goal is to clarify the relationship between different measures of competitive pressure and innovation, especially R\&D investment, based on some rather general assumptions. He considers two different possible measures of competitive pressure with restricted entry (i.e. exogenous market structure), namely: (a) the degree of product substitutability and (b) the number of competitors. In case of free entry (i.e. endogenous market structure) competition is measured by: (a) the degree of product substitutability, (b) the size of the market, and (c) the ease of entry (i.e. the decrease in the entry cost as measured by fixed costs; high fixed costs denote high entry cost.). Vives (2008) constructs two groups of models, one group when no entry takes place and another one with free market entry. These models predict robust effects of each of the above-mentioned competition measures on product (only for free entry) and process innovation, respectively. Process innovation is specified as R\&D expenditure for cost re- 
duction, product innovation as R\&D expenditure for additional product varieties (product differentiation). ${ }^{6}$ The results can be summarised as follows:

(1) For exogenous market structure (restricted entry): More competition in terms of a larger number of firms leads to less R\&D expenditure for cost reduction per firm (process innovation), whereas more competition in terms of a greater product substitutability (without contraction of market demand) leads to more process R\&D expenditure. This means that the two different measures of competition do not lead to the same results. This is an important result that shows the dependence of the direction of impact on innovation on the type of competition measure used.

(2) For endogenous market structure (free entry): An increase of market size or product substitutability increases $R \& D$ expenditure for cost reduction. Increasing the market size may increase or decrease the number of product varieties introduced (product innovation) although the former is more likely to happen than the latter. Increasing product substitutability would decrease product variety (if the market demand does not expand). Finally, lowering entry costs (as measured by fixed costs), thus increasing the number of marker participants, would lower $R \& D$ expenditure for cost reduction per firm (process innovation). This means that also in case of free entry innovation impacts vary by the type of competition measure used. ${ }^{7}$

For this study the case of free market entry is particularly relevant. According to theoretical considerations we would expect that (1) the degree of product substitutability is positively correlated with process innovation effort and negatively correlated with product innovation effort; (2) the extent of fixed costs is positively correlated with process innovation effort and negatively correlated with product innovation effort; and (3) the market size is positively related to process innovation, but the effect with respect to product innovation is a priori not clear. These results allow the formulation of a series of empirically testable hypotheses that we intend to investigate in the first part of the proposed study.

\footnotetext{
${ }^{6}$ Vives (2008) writes that the empirical findings in Aghion et al. (2005) can be reconciled with his theoretical results (as summarized above) under conditions of restricted market entry "provided that competition involves also a liquidation effect that induces cost-reduction effort” (p. 444). Thus, the model of Aghion et al. (2005) can be considered as a special case of his more general analysis.

${ }^{7}$ Stiglitz (1987) developed a model of sunk costs of R\&D investment as a main determinant of competition among innovative firms.
} 


\section{Related Empirical Literature}

We restrict our review of empirical literature to studies on innovation and competition at the firm level that were conducted since the beginning of the nineties. ${ }^{8}$

The studies of Geroski (1990, 1991, 1994), Blundell et al. (1995) and Blundell et al. (1999) are based on UK panel firm data or UK panel industry data in the seventies and eighties and are the most prominent studies cited in economic literature in order to demonstrate the empirical relevance of positive effects of competition (negative effects of market concentration, respectively) on innovation.

As already mentioned the study of Aghion et al. (2005a) is based on a theoretical model that predicts an inverted U-shaped relationship between product market competition as measured by a Lerner Index and innovation as measured by the count of patent applications. Using U.K. firm panel data the authors found strong evidence for this model.

Additional support for the positive effect of competition can be found in the study of Aghion et al. (2005b) that is also based on UK panel firm data for the period 1987-1993. Using measures of market entry at the 4-digit industry level they found positive effects of entry, especially foreign entry, in technologically advanced industries, and weak or even negative ones in technologically laggard industries. This is an interesting result since it introduces a further factor influencing the relationship between competition and innovation, namely, the degree of technological advancement as measured by the difference to industry 'technological frontier' (see Acemoglu et al., 2006).

Pohlmeier (1992) investigated the relationship between innovation and competition in a cross-section of 2,276 German firms of the year 1984. Contrary to his theoretical prediction of a positive sign of the market concentration variable in equations for product and process innovation, he found a negative effect for the estimates based on his preferred econometric method that took account of the simultaneity of concentration and innovation.

\footnotetext{
${ }^{8}$ For a survey of empirical literature see Ahn (2002), especially Table 1.1 in the appendix; for a survey of earlier empirical literature see Gilbert (2006), section III.
} 
In a further study based on data for 1982 German firms for the period 1980-1992, Smolny (2003) found that market power as measured by the frequency of price changes (low frequency implicating high market power) enhances innovation.

In a third study based on a cross-section of 2,775 German firms in the year 1994 Kukuk and Stadler (2005) investigated the influence of competition on innovation using two competition measures, the intensity of technological rivalry measured on a five-point Likert scale and market power as measured by the number of competitors. They found that technological rivalry spurs innovative activities, while the effect of market power appeared to be ambiguous (no effect or weakly negative effect). In sum, there is a discrepancy between the findings of the study of Smolny (showing positive effects of market power) and the other two studies (showing no effects or negative effects of market power) that can be traced back primarily to the different competition indicators used.

Five further studies refer to French, Canadian, Swedish and Spanish firm (or industry) data. Crepon et al. (1996) found in a study for 9,871 French firms in 1991 mixed results with respect to the impact of market concentration on innovation depending on the type of innovation indicator used (small negative effect for patent counts and some other innovation output measures, no effect for R\&D and positive effect for the sales of new products).

Tang (2006) in a study based on data for a cross-section of 8916 Canadian firms in the period 1997-1999 found differentiated effects of competition on innovation depending both on the competition measures and the innovation variables (input or output indicators) used. More concretely, the econometric results show, first, that easy substitution is negatively correlated with innovation activities, second, that constant arrival of competing products is positively associated with R\&D or product innovation, and, third, that quick obsolescence of products is positively related to $R \& D$ and product innovation, but negatively to acquisition of technology and process innovation.

Tingvall and Poldahl (2006) found support for the inverted U-shaped relationship between competition and innovation when a Herfindahl index is used as competition measure but not when price cost margin is used as competition measure. The study is based on Swedish firm data for the period 1990-2000.

Artes (2009) found in a study based on a panel of Spanish firms for the period 1990-2000 a (long-term) positive effect of market power (measured, e.g., by the concentration ratio or the 
price cost margin) on the propensity of conducting $R \& D$, but no (short-term) effect on $R \& D$ expenditures.

In a recent study Lee (2009) based on a unique data set of 1021 firms form several countries (including Canada, Japan, Korea, Taiwan, India and China) found that a firm's response to competitive market pressure depends on its level of technological competence: firms with high level of technological competence increase their R\&D effort, while firms with low technological competence reduce it.

As one can see, the empirical findings with respect to the effect of competition on innovation are mixed depending primarily on the specification of the variables measuring competition and the innovation measures, but there is a discernible tendency to positive effects of competition on innovation.

In the dynamic context, competition both in structural and behavioural terms becomes endogenous. In this case a relevant research question is how technological changes influence competition. Most studies dealing with this topic use market concentration, a structural variable, to measure competition. Geroski and Pomroy (1990) investigated the relationship between innovation and the evolution of market structure. To this end, they developed a dynamic model of market concentration that was applied to 73 UK industries, 1970-1979, and the results were found to be consistent with the hypothesis that innovation causes a decrease of market concentration. These findings were also in accordance with earlier work on the same topic for the UK and the USA respectively.

Gottschalk and Janz (2001) investigated empirically the relationship between innovation and market structure as measured by market concentration within a simultaneous framework at the industry level based on German data for 110 industries for the period 1992-1998. The concentration equation contained a measure for R\&D intensity and proxies for fixed costs and the price elasticity of demand. They found a positive long-run effect of R\&D on market concentration, but a negative impact of market concentration (a positive effect of competition) on R\&D.

\section{Model Specification}

The empirical analysis is based on a two-stage model. In the first stage, we analyze the effect of innovation success in period t-1 on the type of competition in period $t$ (see equation 
[1]). In the second stage, we use the estimated value of the competition variable derived from equation [1] to investigate the effect of competition on innovation input in the following period $(\mathrm{t}+1)$ (see equation [2]).

Building upon the theoretical notions discussed in section 2, we distinguish two dimensions of competition that correspond to the theoretical variables of degree of product substitutability and extent of fixed costs. The former is proxied by the firms' assessment of the easiness of the substitutability of their products, the latter by the firms' assessment of how quickly products become technologically obsolete (slow product obsolescence is related to high fixed costs). The firms answered based on a five-point Likert scale for Switzerland and based on a fourpoint Likert scale for Germany (see also table 1).

Innovation output in t-1 is measured in two ways, (a) by the sales share of innovative products (INNOSALES), and (b) the introduction of cost reducing process innovations. Since we can observe the sales share of innovative products only when a firm has introduced innovative products, a binary variable for product innovators is also included in our model (INNODUM). Innovation input in $\mathrm{t}+1$ is also measured by the logarithm of R\&D expenditures (LNRDEXP). Since firms may decide to refrain from any $R \& D$ activity, we also include a binary variable in our model denoting whether a firm has positive R\&D expenditures (RDYES).

According to the results of comparative statics in Vives (2008) we expect a positive effect of product innovation and a negative effect of process innovation on the competition variable measuring the speed of technological obsolescence. Further, we expect a positive effect for process innovation and a negative effect of product innovation on the competition variable measuring the degree of product substitutability.

In the competition model, it is important to control for the market structure in order to identify the innovation effects on substitutability and obsolescence. Market structure is measured by the number of principal competitors in a firm's main product market as assessed by the firms themselves (NCOMP1: medium number, NCOMP2, large number of competitors). This measure comes close to the theoretically appropriate measure of the number of competitors on the product market that is relevant for a firm. A large number of competitors is expected to increase market uncertainty and to intensify the $R \& D$ race, thus fostering (technological) competition (see Reiganum, 1983; Wernerfelt and Karnani, 1987). As a consequence, we expect a positive effective for this variable for both competition measures. The competition 
equation contains also measures for firm size (SIZE, a priori no clear effects), firm age (AGE, expected negative effect for both competition measures; see, e.g., Lee, 2009), marketing activities (MARKETING, expected negative effect for both competition measures; see, e.g., Mueller and Rogers, 1980; Sutton ,1991 for the role of sunk costs as entry barriers), and degree of exposure to domestic and international competition (DOMESTIC2, INTERNATIONAL, expected positive effect).

The innovation input model includes a variable to control for business cycle effects. We use the difference in sales between $t$ and $t+1$ to capture likely demand and financing effects on innovation input decision (SALESDIF, expected positive effect). We also control for firm characteristics, expecting a positive effect of firm size (see, e.g., Schumpeter, 1942), a negative effect of firm age, and a positive effect of human capital intensity.

In formal terms our two-stage model is as follows (see Table 1 for model variable explanation):

Ordered Probit Model on COMPETITION ${ }^{\mathrm{k}}$

COMPETITION $^{k}{ }_{i t}=\alpha_{0}+\alpha_{1}$ INSTRUMENT $_{i t}+\alpha_{2}$ INNOSALES $_{i t-1}+\alpha_{3}$ INNODUM $_{i t-1}+$ $\alpha_{4}$ COSTRED $_{i t-1}+\alpha_{5} N C O M P 1_{i t}+\alpha_{6} N_{C O M P} 2_{i t}+\alpha_{7} A G E_{i t}+\alpha_{8} S I Z E+\alpha_{9}$ MARKETING $_{i t}+$ [1] $\alpha_{10}$ DOMESTIC $_{i t}+\alpha_{11}$ INTERNATIONAL $_{i t}+\alpha_{12} I_{N D} 1+\ldots+\alpha_{21} I N D 10+e_{i t}$

Heckman-Model on LNRDEXP (intensity)

LNRDEXP $_{i t+1}=\beta_{0}+\beta_{1}$ COMPETITION $\_H{ }^{k}{ }_{i t}+\beta_{2}$ LNRDEXP $_{i t}+\beta_{3}$ SALESDIF $_{i t}+$ $\beta_{4} S_{Z I Z} E_{i t}+\beta_{5} A G E_{i t}+\beta_{6} E D U C_{i t}+\beta_{7} I N D 1+\ldots+\beta_{16} I N D 10+e_{i t}$

Heckman-Model on RDYES (selection)

RDYES $_{i t+1}=\beta_{0}+\beta_{1}$ COMPETITION $_{-}$HAT $^{k}{ }_{i t}+\beta_{2}$ RDYES $_{i t}+\beta_{3}$ SALESDIF $_{i t}+$ $\beta_{4} S_{Z I Z} E_{i t}+\beta_{5} A G E_{i t}+\beta_{6} E D U C_{i t}+\beta_{7} I N D 1+\ldots+\beta_{16} I N D 10+e_{i t}$

while $k$ \& $\left\lfloor\right.$ TECHAGE $_{i t}$, SUBSTITUTE $\left._{i t}\right\rfloor$ 


\section{Data}

The models were estimated using firm-level panel data from the German and Swiss national innovation surveys. These data have been collected through a comprehensive questionnaire in Germany and Switzerland respectively. Both questionnaires are based on the same methodology as the Community Innovation Surveys (CIS). Amongst others, this implies that a stratified random sample of firms from manufacturing and service sectors are surveyed using a standardized mail questionnaire. Innovation activities of firms are measured along the line of the Oslo Manual (OECD and Eurostat, 2005). Like the CIS, our questionnaires include questions on firm characteristics, innovation activities, and R\&D activities. In addition to CIS, we also have a number of questions that relate to the competitive environment of firms. Both surveys are panel surveys, meaning that the same gross sample of firms is surveyed regularly. Since a number of model variables were not part of the standard innovation surveys but only asked in specific years, we were bound to use data from different survey years for Germany (2005-2008) and Switzerland (2002, 2005).

The Swiss innovation survey is conducted by the Swiss Economic Institute (KOF) at the ETH Zurich in a three-year rhythm. For this paper, we use the surveys conducted at the end of 2002 and 2005. Each survey covers firms from manufacturing, construction, and service sectors which have at least five employees. The sample is stratified by 28 industrial sectors and, within each sector, three firm size classes (with full coverage of the upper class of firms). Responses were received from 2,583 firms (39.6\%) and 2,555 firms (38.7\%) for the survey years 2002 and 2005, respectively. Overall, we have an unbalanced firm-panel. Innovation success in terms of sales generated by product innovations and cost reductions based on process innovations was measured as the annual average of the three years 2000 to 2002 (t-1), this information comes from the 2002 survey. This survey also provides data on the competitive environment which relate to the situation at the end of $2002(t)$. $R \& D$ expenditures $(t+1)$ were taken from the 2005 survey and represent the annual average of the R\&D expenditures over the whole period 2003-2005.

The German innovation survey is conducted annually by the Centre of Economic Research (ZEW) located in Mannheim and is known as the Mannheim Innovation Panel (MIP). For this paper, we use the surveys conducted at the beginning of 2005, 2006, 2007 and 2008. Very similar to the Swiss innovation survey, the MIP surveys firms with 5 or more employees in mining, manufacturing, construction and most service sectors (excluding hotels and restau- 
rants, health, education and personal services). The sample is stratified by 52 industrial sectors, eight size classes (with full coverage of the firms with 500 or more employees) and two regions (East and West Germany). The number of responses was 5,476 (in 2005), 4,728 (in 2006), 5,663 (in 2007) and 6,110 (in 2008). Response rates were 19.6\%, 27.2\%, 20.5\% and 32.0\%, respectively. The somewhat higher response in 2006 and 2008 reflects the fact that surveys conducted in even years focus on a smaller stratified sample which focuses on firms that participated in recent survey waves (see Janz et al., 2001, and Peters, 2008, for the MIP survey methodology). Since response rates of the MIP are low, each year a comprehensive non-response survey is conducted, targeting a net sample of about 4,000 to 4,500 nonresponding firms through a telephone survey which collects some key information on the firms' innovation activities. Non-response surveys regularly show that there is no significant bias among the responding firms in terms of innovation activities. Innovation success variables for the German data relate to sales with new products and cost savings from process innovation in the year 2004 which have been achieved by innovations introduced in three years 2002 to 2004 (t-1). Data on the competitive environment relate to the beginning of the year $2005(\mathrm{t})$. Both innovation success and competitive environment variables come from the 2005 survey. $R \& D$ expenditures in $t+1$ were taken from the 2006 to 2008 surveys and represent the annual average of the period 2005-2007.

Since the dependent variable in [1] is a categorical variable (5 categories in the Swiss case and 4 categories in the German case) we applied an ordered probit procedure (applied software STATA version 11) with heteroscedasticity robust standard errors. Models [2, 3] are estimated through a 'Heckman' two step procedure. Since the type of competition is an endogenous variable we inserted the estimated values from Model (1) instead of the original variable and bootstrapped the standard errors with 200 replications (an increase in the number of replications does not affect the results significantly). The selection part and the intensity part of the Heckman procedures are identically specified with the difference that the selection equation includes RDYES $\mathrm{t}_{\mathrm{t}}$ instead of LNRDEXP.

As already mentioned COMPETITION ${ }^{\mathrm{k}}$ was measured through two different variables, i.e. TECHAGE and SUBSTITUTE. Both variables are relying on firm's assessments of their market environment. Since competition is endogenous and we included competition as an explanatory variable in models [2 and 3], we needed valid instruments (INSTRUMENT) for both countries (see Wooldridge 2006). The instruments for TECHAGE are TAXBURDEN (for the Swiss sample) and DOMINANCE (for the German sample). Both variables can be 
expected to be exogenous since it is very unlikely that a single firm can influence or determine the tax policies of a country or the size of its competitors. COPY (for Switzerland) and SERVQUAL (for Germany) are the instruments for the SUBSTITUTE equation. COPY is also a variably that is very difficult to influence by a single firms, since it is very difficult to determine the effort competitors make to copy your innovations. SERVQUAL is assumed to represent structural features of the channels through which firms compete in a given market. Thus, it is expected that both instruments lie beyond the influence of a single firm that means they are exogenous to the single firm's activities. Certainly we conducted econometric tests in order confirm the validity of our instruments (see Annex Table A1 and A2). It can be shown that the instruments are not correlated with the residuum of the model and with the dependent variables. However they are correlated as they have to with the endogenous competition variables.

The variable for the share of sales generated by innovative products (INNOSALES) contains many zeros as many firms did not introduce any new products in period $\mathrm{t}-1$. As the effects of having generated no sales with new products may be different from having generated some sales, we modelled the step from zero to any innovative sales with a separate variable INNODUM (value 0 if INNOSALES equals zero and 1 if INNOSALES is positive). COSTRED in t- 1 is a binary variable that takes the value 1 if a firm reported cost reductions due to process innovations and 0 otherwise. NCOMP1 and NCOMP2 measure the number of principal competitors of a firm (NCOMP1 equals 1 if there are more than 5 and less than 15 competitors ( 0 otherwise) and NCOMP2 equals 1 if there are 16+ competitors and 0 otherwise; less than 5 competitors is the reference variable). We further control for firm age (AGE: logarithm of firm age measured as 2002 minus year of foundation) and SIZE (logarithm of the number of employees in full-time equivalents).

The firms have been asked if they changed their marketing concepts significantly within the last three years. Marketing is an expensive activity and it is assumed that a significant change in marketing concepts indicates the importance of such activities for a firm and this may discourage firms from entering the respective market. Thus, MARKETING is our proxy for barriers to market entry. It is expected that MARKETING is negatively related to competition.

The geography of sales markets may also play a role in terms of competition type. Regional or domestic markets do not have a sufficiently great sales potential that innovation activities can be pursued systematically. International or even global markets are necessary to address a 
greater number of potential users. Thus we would expect that our proxies for national markets (DOMESTIC2) and international markets (INTERNATIONAL) are positively related to technology competition (DOMESTIC1 is the reference) and geography is expected to be negatively related or unrelated to substitutive competition. We also control for industry specific variance through a series of industry dummies (10 for the Swiss sample, 22 for the German sample).

Moreover we want to know how competition affects incentives for investing in R\&D both in terms of deciding to engage in any type of $R \& D$ activity and in terms of the level of $R \& D$ spending. In order to investigate this question we applied a Heckman procedure with bootstrapped standard errors. $R \& D$ expenditure in period $t+1$ was separated in a binary part (RDYES) that equals 1 if a firm has positive R\&D expenditure in $t+1$ and 0 otherwise and a continuous part LNRDEXP (natural logarithm of the amount of R\&D expenditure). Both the selection equation on RDYES and the continuous part on LNRDEXP contained the lagged variables for RDYES and LNRDEXP, respectively. R\&D expenditure in $t+1$ referred to the average of a three year period following $t$ in order to avoid too strong business cycles impacts on the level of R\&D expenditure. SALESDIF is the difference between the natural logarithm of sales in $t+1$ and $t$ and captures short term business cycle effects on a firms R\&D expenditure. EDUC is the share of employees with a university degree and should capture a firm's absorptive capacities. The estimated values of the two competition variables (COMPETITION_HAT ${ }^{\mathrm{k}}$ ) were taken from the ordered probit estimates of the first stage.

\section{Results}

Looking first at some descriptive statistics (see Table 2) it is confirmed that $R \& D$ is a very stable activity. The share of $R \& D$ active firms in our sample is similar in the Swiss and German sample and does not change much between the two periods of investigation $(45 \%$ and $39 \%$, respectively, in first period and $40 \%$ and $42 \%$, respectively, in the second period). On average firms find themselves less frequently exposed to 'product obsolesce' (TECHAGE) compared to substitutive competition (SUBSTITUTE). The sales share of innovative products amounts to $20 \%$ on average in the Swiss sample and to $13 \%$ in the German sample. Some striking results are found for the share of firms that are exposed to a medium or high number of principal competitors. In the Swiss sample, $40 \%$ of the firms in our sample report to have between 6 and 15, and 34\% claim that there are more than 16 principal competitors. In the 
German sample, the respective shares are clearly lower (20\% for each category), implying that a large share of firms state that the number of principal competitors is below 6 . We assume that these differences reflect to some extent also the different response categories in the two questionnaires (Switzerland: up to 5, 6-10, 11-15, 16-50, more than 50; Germany: 0, 1-5, 6-15, more than 15). The share of employees with tertiary level education (EDUC) is around 13\% in Switzerland and 19\% in Germany. New marketing concepts have been introduced by 35\% of Swiss firms and 25\% of German firms. 33\% of Swiss firms serve international markets with their product, whereas only $10 \%$ of German firms, reflecting the different sizes of domestic markets. The firm share mainly serving local and regional markets is $43 \%$ and $50 \%$, respectively.

We obtained very stable results for both countries if we look at our econometric results (see Table 3 and Table 4). Innovation output in t-1 as measured by the sales share of innovative products in $\mathrm{t}-1$ is positively related to the rate of product obsolescence, i.e. negatively related to the level of fixed costs in t, and negatively to the degree of substitutability in both countries. These results were in line with the theoretical expectations in Vives (2008). The former result indicated that primarily product innovations are an essential characteristic for technology-oriented competition. The latter result pointed at relatively few product innovation activities of firms with high product substitutability; it seems that product innovations are a too expensive activity for firms with easily substitutable products. Predominantly large firms find themselves in such a competitive environment. Furthermore, the number of competitors increases with higher levels of both competition variables. Innovation output in t-1 as measured by the cost reduction variable in $\mathrm{t}-1$ is positively correlated to the degree of substitutability in Germany and unrelated in Switzerland. This is very much in line with the theoretical expectations. With respect to technology competition (product obsolesces) the results showed some divergence from theoretical expectations. We see a negative relationship between cost reduction measures (COSTRED) and technology competition (TECHAGE). Thus cost reduction measures seem to be of minor importance for firms exposed to greater technology obsolesces.

Knowing that innovation output is an important factor for explaining the type of competition we further wanted to know how competition impacts future $R \& D$ investments. Here, we found again different results for the two competition variables. While high product obsolescence provided positive incentives for $R \& D$ investments (that are primarily oriented to product innovations), high substitutability provided negative incentives for $R \& D$ investment. Thus, we found for product substitutability a 'vicious circle', i.e. few innovation activities in 
$\mathrm{t}-1$ and low incentives for $\mathrm{R} \& \mathrm{D}$ investments in $\mathrm{t}+1$. That means that firms in such markets are under increasing cost pressure and cannot (or to a much lesser extent) afford innovative activities that lead to product innovations. In the medium term such firms are likely to outsource their production to other, cheaper countries than Switzerland and Germany. This could cause additional problems for employment, not at least, since predominantly larger firms find themselves exposed to substitution competition. We found a completely different picture for competition referring to a high rate of product obsolescence. This type of competition is nurtured through innovation activities on the product level and it also leads to greater R\&D investments in the future period. Furthermore, we found that size is clearly positively related to R\&D (0/1) and R\&D investments.

\section{Conclusions}

Firstly, we modelled the relationship between past innovation output, competition, and future innovation input in a dynamic econometric setting. Secondly, we distinguished two different dimensions of competition that correspond to the theoretical variables of product substitutability and extent of fixed costs. The former was proxied by the firms' assessment of the easiness of the substitutability of their products, the latter by the firms' assessment of how quickly products become technologically obsolete (slow product obsolescence is related to high fixed costs). Thirdly, we distinguished two types of innovation output: (a) cost reductions due to process innovation and (b) sales of innovative products. By relating the type of innovation to the type of competition we could point at the interdependency of innovation policy and competition policy, two usually separate fields of policy making. This is of particular importance for countries like Germany or Switzerland that rely on innovation as the main competitive advantage in international trade.

From a policy point of view innovation policy and competition policy are strongly related, just like in the tradition of Schumpeterian economics. However, in Switzerland as well as in Germany both policies are working in different directions in terms of innovation performance. While competition policy focuses on larger markets, thus contributing to an increase of product substitutability that in turn leads to lower R\&D investments, innovation policies are working against this direction; they promote predominantly product innovation, thus fostering technological obsolescence of products that in turn increases R\&D expenditures. Thus both types of policies should not only be related, they should be also coordinated. 


\section{References}

Acemoglu, D., P. Aghion and F. Zilibotti (2006), Distance to Frontier, Selection, and Economic Growth, Journal of the European Economic Association 4, 37-74.

Aghion, P., R. Blundell, R. Griffith and P. Howitt (2005a), Competition and Innovation: An Inverted U Relationship, Quarterly Journal of Economics 120, 701-728.

Aghion, P., R. Blundell, R. Griffith and P. Howitt (2005b), The Effects of Entry on Incumbent Innovation and Productivity, CEPR Discussion Paper No. 5323, London.

Ahn, S. (2002), Competition, Innovation and Productivity Growth: A Review of Theory and Evidence, OECD Economics Department Working Papers No. 317, Paris.

Arrow, K.J. (1962), Economic Welfare and the Allocation of Resources in Invention, in: R.R. Nelson (Ed.), The Rate and Direction of Economic Activity, New York: Princeton University Press.

Artes, J. (2009), Long-run Versus Short-run Decisions: R\&D and Market Structure in Spanish Firms, Research Policy 38, 120-132.

Blundell, R., R. Griffith and J. Van Reenen (1995), Dynamic Count Data Models of Technological Innovation, Economic Journal 105, 333-344.

Blundell, R., R. Griffith and J. Van Reenen (1999), Market Share, Market Value and Innovation in a Panel of British Manufacturing Firms, Review of Economic Studies 66, 529-554.

Crépon, B., E. Duguet and I. Kabla (1996), Schumpeterian Conjectures: A Moderate Support from Various Innovation Measures, in: A. Kleinknecht (ed.), Determinants of Innovation, London: Macmillan.

Dasgupta, P. and J. Stiglitz (1980), Industrial Structure and the Nature of Innovative Activity, Economic Journal 90, 266-293.

Dixit, A. and J. Stiglitz (1977), Monopolistic Competition and Optimum Product Diversity, American Economic Review 67, 297-308.

Gaffard, J.L. (2008), Innovation, Competition, and Growth. Schumpeterian Ideas in a Hicksian Framework, Journal of Evolutionary Economics 18, 295-311.

Gilbert, R. (2006), Looking for Mr. Schumpeter: Where Are We in the CompetitionInnovation Debate, in: J. Lerner and S. Stern (eds.), Innovation Policy and Economy, Cambridge: MIT Press.

Geroski, P. (1990), Innovation, Technological Opportunity and Market Structure, Oxford Economic Papers 42, 586-602.

Geroski, P. (1991), Market Dynamics and Entry, Cambridge: Basil Blackwell.

Geroski, P., and R. Pomroy (1990), Innovation and Evolution of Market Structure, Journal of Industrial Economics 38, 299-314. 
Geroski, P. (1994), Market Structure, Corporate Performance and Innovative Activity, Oxford: Oxford University Press.

Gottschalk, S. and N. Janz (2001), Innovation Dynamics and Endogenous Market Structure, ZEW Discussion Paper No. 01-39, Mannheim.

Jaffe, A.B. (1986), Technology Opportunity and Spillovers of R\&D: Evidence From Firms' Patents, Profits and Market Value, American Economic Review 76, 984-1001.

Janz, N., G. Ebling, S. Gottschalk and H. Niggemann (2001), The Mannheim Innovation Panels (MIP and MIP-S) of the Centre for European Economic Research (ZEW), Journal of Applied Social Science Studies 121, 123-129.

Kukuk, M. and M. Stadler (2005), Market Structure and Innovation Races, Jahrbücher für Nationalökonomie und Statistik 225, 427-440.

Lee, C.Y. (2009), Competition Favours the Prepared Firm: Firms’ R\&D Responses to Competitive Market Pressure, Research Policy 38, 861-870.

Mueller, W. and R. Rogers (1980), The Role of Advertizing in Changing Concentration of Manufacturing Industries, Review of Economics and Statistics 62, 89-96.

Nelson, R.R. and S.G. Winter (1977), Simulation of Schumpeterian Competition, American Economic Review 67, 271-276.

OECD and Eurostat (2005), The Oslo Manual. Guidelines for Collecting and Interpreting Innovation Data, Third Edition, Paris: OECD.

Peters, B. (2008), Innovation and Firm Performance. An Empirical Investigation for German Firms, ZEW Economic Studies 38, Heidelberg: Physica.

Pohlmeier, W. (1992), On the Simultaneity of Innovations and Market Structure, Empirical Economics 17, 253-272.

Reiganum, J. (1983), Uncertain innovation and the persistence of monopoly. American Economic Review 73, 741-748.

Scherer, F.M. and K. Huh (1992), R\&D Reactions to High-technology Import Competition, Review of Economics and Statistics 74, 202-212.

Schmutzler, A. (2010), The Relation between Competition and Innovation - Why Is It Such a Mess?, Socioeconomic Institute, University of Zurich Working Paper No. 0716, revised version, Zurich.

Schumpeter, J.A. (1934), The Theory of Economic Development, Cambridge: Harvard University Press.

Schumpeter, J.A. (1942), Capitalism, Socialism, and Democracy, New York: Harper and Brothers. 
Smolny, W. (2003), Determinants of Innovation Behaviour and Investment Estimates for West-German Manufacturing Firms, Economics of Innovation and New Technology 12, 449-463.

Spence, M. (1984), Cost Reduction, Competition, and Industry Performance, Econometrica 52, 101-121.

Stiglitz, J.E. (1987), Technological Change, Sunk Costs and Competition, Brookings Papers on Economic Activity 1987(3), 883-947.

Tang, J. (2005), Competition and Innovation Behaviour, Research Policy 35, 68-72.

Tingvall, P.G. and A. Polsdahl (2006), Is There Really an Inverted U-shaped Relation between Competition and R\&D?, Economics of Innovation and New Technology 15, 101118.

Vives, X. (2008), Innovation and Competitive Pressure, Journal of Industrial Economics 56, 419-469. 
Table 1a: List of variables, Swiss data

\begin{tabular}{|c|c|}
\hline TECHAGE $_{\text {it }}$ & $\begin{array}{l}\text { Firm's answer on a five point likert scale ( } 1 \text { not applicable ... } 5 \text { greatly applicable) to the } \\
\text { questions if 'products and services are ageing quickly'. (COMPETITION) }\end{array}$ \\
\hline TECHAGE_HAT $_{\text {it }}$ & Estimated values of TECHAGE $\mathrm{it}_{\mathrm{it}}$ \\
\hline SUBSTITUTE $_{\text {it }}$ & $\begin{array}{l}\text { Firm's answer on a five point likert scale ( } 1 \text { not applicable ... } 5 \text { greatly applicable) to the } \\
\text { questions if their 'products are easily substituted by products from other firms'. (COM- } \\
\text { PETITION) }\end{array}$ \\
\hline $\begin{array}{l}\text { SUBSTI- } \\
\text { TUTE_HAT }_{\text {it }}\end{array}$ & Estimated values of SUBSTITUTE $\mathrm{it}_{\mathrm{i}}$ \\
\hline $\mathrm{COPY}_{\text {it }}$ & $\begin{array}{l}\text { Firm's answer on a five point likert scale ( } 1 \text { not applicable } \ldots 5 \text { greatly applicable) to the } \\
\text { question whether it is easy to copy their innovations. (INSTRUMENT) }\end{array}$ \\
\hline TAXBURDEN $_{\text {it }}$ & $\begin{array}{l}\text { Firm's answer on a five point likert scale ( } 1 \text { not applicable ... } 5 \text { greatly applicable) to the } \\
\text { question whether the tax burden is too high for innovative activities. (INSTRUMENT) }\end{array}$ \\
\hline INNOSALES $_{\mathrm{it}-1}$ & Sales share of new and essentially modified products between 2000 and 2002 \\
\hline INNODUM $_{\text {it-1 }}$ & Binary variable whether a firm has been innovative between 2000 and 2002 (yes/no). \\
\hline COSTRED $_{\text {it- } 1}$ & Cost reductions due to process innovations between 2000 and 2002 (yes/no) \\
\hline $\mathrm{NCOMP} 1_{\text {it }}$ & $\begin{array}{l}\text { Number of principal competitors is more than } 5 \text { and less than } 16 \text { (yes/no; reference } 5 \text { or } \\
\text { less competitors) }\end{array}$ \\
\hline $\mathrm{NCOMP}_{\text {it }}$ & Number of principal competitors 16+ (yes/no) \\
\hline $\mathrm{AGE}_{\mathrm{it}}$ & Natural logarithm of firm age measured as 2002 minus year of foundation \\
\hline $\mathrm{SIZE}_{\text {it }}$ & Natural logarithm of the full-time equivalents of a firm in 2001 \\
\hline MARKETING $_{\text {it }}$ & $\begin{array}{l}\text { Essentially modified or new marketing methods introduced between } 2000 \text { and } 2002 \\
\text { (yes/no) }\end{array}$ \\
\hline DOMESTIC $2_{\text {it }}$ & The main sales market is domestic (more than $50 \mathrm{~km}$ radius but national) (yes/no) \\
\hline INTERNATIONAL $_{\text {it }}$ & The main sales market is international (yes/no) \\
\hline $\operatorname{LNRDEXP}_{\mathrm{it}+1}$ & Natural logarithm of R\&D expenditures (average across three years; 2003-2005) \\
\hline LNRDEXP ${ }_{\text {it }}$ & Natural logarithm of R\&D expenditures (average across three years; 2000-2002) \\
\hline SALESDIF $_{\text {it }}$ & Difference of the logarithm of sales in 2004 and logarithm of sales in 2001 \\
\hline $\mathrm{EDUC}_{\mathrm{it}}$ & Share of employees with tertiary level education on total employees \\
\hline RDYES $_{\mathrm{it}+1}$ & R\&D activities between 2003 and 2005 (yes/no) \\
\hline RDYES $_{\text {it }}$ & R\&D activities between 2000 and 2002 (yes/no) \\
\hline RESID_T & Residuum of the 'heckman' estimation on LNRDEXP ${ }_{\mathrm{it}+1}$ with the TECHAGE variable \\
\hline RESID_S & $\begin{array}{l}\text { Residuum of the 'heckman' estimation on LNRDEXP }{ }_{\text {it }+1} \text { with the SUBSTITUTE vari- } \\
\text { able }\end{array}$ \\
\hline IND1 ... IND10 & $\begin{array}{l}\text { Ten industry dummies (two digit level): (Food, Textile, Clothing (1); Wood processing, } \\
\text { Paper (2); Chemicals, Rubber/Plastic products, Machinery, Electrical machinery (3), } \\
\text { Publishing, Other non-metallic mineral products, Metal, Metalworking (4); Elec- } \\
\text { tronic/instruments, Vehicles (5), Watches, Other manufacturing, Energy/water (6); Retail } \\
\text { trade, Hotels and Restaurants (7); Wholesale, Transportation and Telecommunication } \\
\text { (8); Banking/Insurance and Real Estate (9); Computer Service, Business Service, Per- } \\
\text { sonal Service (10). Reference category is Construction. }\end{array}$ \\
\hline
\end{tabular}


Table 1b: List of variables, German data

\begin{tabular}{|c|c|}
\hline TECHAGE ${ }_{\text {it }}$ & $\begin{array}{l}\text { Firm's answer on a five point likert scale ( } 1 \text { not applicable ... } 4 \text { greatly applicable) to the } \\
\text { questions if 'products and services are ageing quickly' (COMPETITION) }\end{array}$ \\
\hline TECHAGE_HAT $_{\text {it }}$ & Estimated values of TECHAGE $\mathrm{Tit}_{\mathrm{it}}$ \\
\hline SUBSTITUTE $_{\mathrm{it}}$ & $\begin{array}{l}\text { Firm's answer on a five point likert scale ( } 1 \text { not applicable ... } 4 \text { greatly applicable) to the } \\
\text { questions if their 'products are easily substituted by products from other firms' (COM- } \\
\text { PETITION) }\end{array}$ \\
\hline $\begin{array}{l}\text { SUBSTI- } \\
\text { TUTE_HAT }_{\text {it }}\end{array}$ & Estimated values of SUBSTITUTE $\mathrm{it}_{\mathrm{i}}$ \\
\hline DOMINANCE $_{\text {it }}$ & $\begin{array}{l}\text { Firm's state that dominance by large enterprises is an highly important obstacle for inno- } \\
\text { vative activities (INSTRUMENT) }\end{array}$ \\
\hline SERVQUAL $_{\text {it }}$ & $\begin{array}{l}\text { Firm's state that either product quality or service and flexibility are the most important } \\
\text { competitive factors in their market (INSTRUMENT) }\end{array}$ \\
\hline INNOSALES $_{\mathrm{it}-1}$ & $\begin{array}{l}\text { Sales share in } 2004 \text { of new and significantly improved products introduced between } \\
2002 \text { and } 2004\end{array}$ \\
\hline INNODUM $_{\text {it-1 }}$ & Binary variable whether a firm had positive innovative sales in 2004 (yes/no). \\
\hline COSTRED $_{\text {it- } 1}$ & $\begin{array}{l}\text { Cost reduction in } 2004 \text { due to process innovations introduced between } 2002 \text { and } 2004 \\
\text { (yes/no) }\end{array}$ \\
\hline NCOMP $1_{\text {it }}$ & $\begin{array}{l}\text { Number of principal competitors is more than } 5 \text { and less than } 16 \text { (yes/no; reference } 5 \text { or } \\
\text { less competitors) }\end{array}$ \\
\hline $\mathrm{NCOMP} 2_{\text {it }}$ & Number of principal competitors 16+ (yes/no). \\
\hline $\mathrm{AGE}_{\mathrm{it}}$ & Natural logarithm of firm age (2005 - year of foundation) \\
\hline $\mathrm{SIZE}_{\mathrm{it}}$ & Natural logarithm of the full-time equivalents of a firm in 2004 \\
\hline MARKETING $_{\text {it }}$ & Significant changes in marketing methods introduced between 2002 and 2004 (yes/no) \\
\hline DOMESTIC $2_{\text {it }}$ & The main sales market is domestic (more than $50 \mathrm{~km}$ radius but national) (yes/no) \\
\hline INTERNATIONAL $_{\text {it }}$ & The main sales market is international (yes/no) \\
\hline LNRDEXP $_{i t+1}$ & Natural logarithm of R\&D expenditures (average across three years; 2005-2007) \\
\hline $\mathrm{LNRDEXP}_{\text {it }}$ & Natural logarithm of R\&D expenditures in 2004 \\
\hline SALESDIF $_{\text {it }}$ & $\begin{array}{l}\text { Difference of the logarithm of sales in 2005-2007 (annual average) and logarithm of } \\
\text { sales in } 2004\end{array}$ \\
\hline $\mathrm{EDUC}_{\mathrm{it}}$ & Share of employees with tertiary level education on total employees \\
\hline RDYES $_{i t+1}$ & R\&D activities between 2005 and 2007 (yes/no) \\
\hline RDYES $_{\text {it }}$ & R\&D activities between 2002 and 2004 (yes/no) \\
\hline RESID_T & Residuum of the 'heckman' estimation on LNRDEXP ${ }_{i t+1}$ with TECHAGE variable \\
\hline RESID_S & Residuum of the 'heckman' estimation on LNRDEXP ${ }_{i t+1}$ with SUBSTITUTE variable \\
\hline IND1 ... IND22 & $\begin{array}{l}22 \text { industry dummies (two digit level): Mining (1) Food, beverages, tobacco (2); Textile, } \\
\text { clothing (3); Wood, paper, printing, publishing (4); Chemicals, pharmaceuticals, petro- } \\
\text { leum (5); Rubber/plastic products (6); Glass/ceramics/concrete products (7); Machinery } \\
\text { (8); Electrical/electronics products (9); Instruments (10); Vehicles (11); Furniture, other } \\
\text { manufacturing, Recycling (12); Energy/water (13); Construction (14); Wholesale (1); } \\
\text { Retail, car repair (16); Transportation and postal services (17); Financial services (18); } \\
\text { Computer services, telecommunication (19); Engineering services, R\&D (20); Consult- } \\
\text { ing, advertising (21); Other business services, real estate, renting (22); reference category } \\
\text { is Metal production and processing. }\end{array}$ \\
\hline
\end{tabular}


Table 2: Descriptive statistics of model variables

\begin{tabular}{|c|c|c|c|c|c|c|}
\hline \multirow[b]{2}{*}{ Variables } & \multicolumn{3}{|c|}{ Swiss Sample } & \multicolumn{3}{|c|}{ German Sample } \\
\hline & Mean & $\begin{array}{l}\text { Standard } \\
\text { Deviation }\end{array}$ & $\begin{array}{l}\text { No. of ob- } \\
\text { servations }\end{array}$ & Mean & $\begin{array}{r}\text { Standard } \\
\text { Deviation }\end{array}$ & $\begin{array}{l}\text { No. of ob- } \\
\text { servations }\end{array}$ \\
\hline $\operatorname{LNRDEXP}_{\mathrm{it}+1}$ & 12.23 & 2.93 & 481 & 12.09 & 2.65 & 1,190 \\
\hline $\operatorname{LNRDEXP}_{\text {it }}$ & 12.49 & 2.11 & 548 & 12.27 & 2.40 & 1,106 \\
\hline RDYES $_{\mathrm{it}+1}$ & 0.40 & 0.49 & 1,214 & 0.42 & 0.49 & 2,864 \\
\hline RDYES $_{\text {it }}$ & 0.45 & 0.50 & 1,214 & 0.39 & 0.49 & 2,864 \\
\hline TECHAGE $_{\text {it }}$ & 2.34 & 1.12 & 1,214 & 2.22 & 0.87 & 2,864 \\
\hline SUBSTITUTE $_{\text {it }}$ & 3.40 & 1.19 & 1,214 & 2.78 & 0.95 & 2,864 \\
\hline $\mathrm{COPY}_{\mathrm{it}}$ & 2.35 & 1.25 & 1,214 & & & \\
\hline TAXBURDEN $_{\text {it }}$ & 1.93 & 1.15 & 1,214 & & & \\
\hline DOMINANCE $_{\mathrm{it}}$ & & & & 0.09 & 0.29 & 2,864 \\
\hline SERVQUAL $_{\text {it }}$ & & & & 0.49 & 0.50 & 2,864 \\
\hline SALESDIF $_{\text {itt }}$ & -0.02 & 0.51 & 1,214 & 0.13 & 0.52 & 2,864 \\
\hline INNOSALES $_{\text {it-1 }}$ & 20.03 & 25.50 & 1,214 & 13.31 & 22.21 & 2,864 \\
\hline INNODUM $_{\text {it-1 }}$ & 0.59 & 0.49 & 1,214 & 0.45 & 0.50 & 2,864 \\
\hline COSTRED $_{\text {it- } 1}$ & 0.20 & 0.40 & 1,214 & 0.20 & 0.40 & 2,864 \\
\hline NCOMP $1_{\text {it }}$ & 0.40 & 0.49 & 1,214 & 0.20 & 0.40 & 2,864 \\
\hline $\mathrm{NCOMP}_{\text {it }}$ & 0.34 & 0.48 & 1,214 & 0.20 & 0.40 & 2,864 \\
\hline$A G E_{i t}$ & 3.75 & 0.84 & 1,214 & 2.96 & 0.96 & 2,864 \\
\hline $\mathrm{SIZE}_{\mathrm{it}}$ & 3.97 & 1.40 & 1,214 & 3.81 & 1.84 & 2,864 \\
\hline $\mathrm{EDUC}_{\mathrm{it}}$ & 13.32 & 13.45 & 1,214 & 19.43 & 23.19 & 2,864 \\
\hline MARKETING $_{\text {it }}$ & 0.35 & 0.47 & 1,214 & 0.25 & 0.44 & 2,864 \\
\hline DOMESTIC $_{\text {it }}$ & 0.24 & 0.43 & 1,214 & 0.40 & 0.49 & 2,864 \\
\hline INTERNATIONAL $_{\mathrm{it}}$ & 0.33 & 0.47 & 1,214 & 0.10 & 0.30 & 2,864 \\
\hline
\end{tabular}


Table 3: Determinants of type of competition: parameter estimates of ordered probit regressions

\begin{tabular}{|c|c|c|c|c|}
\hline & \multicolumn{2}{|c|}{ Switzerland } & \multicolumn{2}{|c|}{ Germany } \\
\hline & TECHAGE $_{\text {it }}$ & SUBSTITUTE $_{\mathrm{it}}$ & TECHAGE $_{\mathrm{it}}$ & SUBSTITUTE $_{\mathrm{it}}$ \\
\hline \multirow[t]{2}{*}{ TAXBURDEN $_{\text {it }} /$ DOMINANCE $_{\text {it }}$} & $0.092 * * *$ & & $0.388 * * *$ & \\
\hline & $(0.030)$ & & $(0.072)$ & \\
\hline \multirow[t]{2}{*}{$\mathrm{COPY}_{\text {it }} / \mathrm{SERVQUAL}_{\mathrm{it}}$} & & $0.093 * * *$ & & $-0.156^{* * *}$ \\
\hline & & $(0.026)$ & & $(0.041)$ \\
\hline \multirow[t]{2}{*}{ INNOSALES $_{\text {it-1 }}$} & $0.007 * * *$ & $-0.004 * * *$ & $0.005^{* * *}$ & $-0.430 * * *$ \\
\hline & $(0.002)$ & $(0.001)$ & $(0.001)$ & $(0.117)$ \\
\hline \multirow[t]{2}{*}{ INNODUM $_{\mathrm{it}-1}$} & $0.270 * * *$ & $0.148^{*}$ & $0.332 * * *$ & $0.095^{*}$ \\
\hline & $(0.088)$ & $(0.084)$ & $(0.057)$ & $(0.055)$ \\
\hline \multirow[t]{2}{*}{ COSTRED $_{\mathrm{it}-1}$} & $-0.258 * * *$ & -0.053 & $0.151^{* * *}$ & $0.118 * *$ \\
\hline & $(0.084)$ & $(0.079)$ & $(0.053)$ & $(0.053)$ \\
\hline \multirow[t]{2}{*}{ NCOMP $1_{\text {it }}$} & $0.163^{* *}$ & 0.021 & $0.087^{*}$ & $0.225 * * *$ \\
\hline & $(0.076)$ & $(0.079)$ & $(0.051)$ & $(0.052)$ \\
\hline \multirow[t]{2}{*}{$\mathrm{NCOMP}_{\text {it }}$} & $0.267 * * *$ & 0.112 & $0.204^{* * *}$ & $0.292 * * *$ \\
\hline & $(0.082)$ & $(0.083)$ & $(0.055)$ & $(0.054)$ \\
\hline \multirow[t]{2}{*}{$\mathrm{AGE}_{\mathrm{it}}$} & 0.035 & 0.067 & $0.062 * * *$ & 0.027 \\
\hline & $(0.040)$ & $(0.043)$ & $(0.023)$ & $(0.023)$ \\
\hline \multirow[t]{2}{*}{$\mathrm{SIZE}_{\mathrm{it}}$} & 0.022 & $0.070 * * *$ & $-0.031 * *$ & $0.069 * * *$ \\
\hline & $(0.025)$ & $(0.026)$ & $(0.013)$ & $(0.014)$ \\
\hline \multirow[t]{2}{*}{ MARKETING $_{\text {it }}$} & 0.093 & 0.015 & 0.007 & $0.183^{* * *}$ \\
\hline & $(0.067)$ & $(0.067)$ & $(0.050)$ & $(0.047)$ \\
\hline \multirow[t]{2}{*}{ DOMESTIC $_{\text {it }}$} & -0.045 & 0.039 & 0.060 & $-0.087^{*}$ \\
\hline & $(0.080)$ & $(0.081)$ & $(0.047)$ & $(0.047)$ \\
\hline \multirow[t]{2}{*}{ INTERNATIONAL $_{\text {it }}$} & 0.083 & -0.106 & 0.005 & -0.102 \\
\hline & $(0.083)$ & $(0.081)$ & $(0.077)$ & $(0.073)$ \\
\hline \multirow[t]{2}{*}{ Cut1 } & $0.586 * * *$ & -0.243 & $-0.514 * * *$ & -0.856 \\
\hline & $(0.210)$ & $(0.222)$ & $(0.105)$ & $(0.109)$ \\
\hline \multirow[t]{2}{*}{ Cut2 } & $1.450 * * *$ & $0.387 *$ & $0.883 * * *$ & -0.006 \\
\hline & $(0.211)$ & $(0.220)$ & $(0.105)$ & $(0.108)$ \\
\hline \multirow[t]{2}{*}{ Cut3 } & $2.292 * * *$ & $1.122 * * *$ & $1.902 * * *$ & $1.120 * * *$ \\
\hline & $(0.213)$ & $(0.221)$ & $(0.110)$ & $(0.109)$ \\
\hline \multirow[t]{2}{*}{ Cut4 } & $3.103^{* * *}$ & $2.070 * * *$ & & \\
\hline & $(0.220)$ & $(0.226)$ & & \\
\hline No. of observations & 1,214 & 1,214 & 2,864 & 2,864 \\
\hline Wald chi ${ }^{2}$ & 143.385 & 65.983 & 491.71 & 240.35 \\
\hline Prob $>\mathrm{chi}^{2}$ & 0.000 & 0.000 & 0.000 & 0.000 \\
\hline
\end{tabular}

Note: Ordered probit estimation with heteroscedasticity robust standard errors in brackets.

$*, * *, * * *$ indicates a significant level of $90 \%, 95 \%$, and $99 \%$ respectively. Industry dummies included. 
Table 4: Type of competition and future R\&D expenditures: estimation results of twostep heckman models

\begin{tabular}{|c|c|c|c|c|}
\hline & \multicolumn{2}{|c|}{ Switzerland } & \multicolumn{2}{|c|}{ Germany } \\
\hline & Coefficient & Standard error & Coefficient & Standard error \\
\hline \multicolumn{5}{|l|}{ Dependent variable: $L N R D E X P_{i t+1}$} \\
\hline SUBSTITUTE_HAT $_{\text {it }}$ & $-1.595 * *$ & $(0.806)$ & $-0.730 * * *$ & $(0.210)$ \\
\hline TECHAGE_HAT $_{\text {it }}$ & $1.273^{* *}$ & $(0.536)$ & $0.619 * * *$ & $(0.191)$ \\
\hline $\mathrm{LNRDEXP}_{\text {it }}$ & 0.109 & $(0.079)$ & $0.462 * * *$ & $(0.029)$ \\
\hline SALESDIF $_{\text {it }}$ & $0.654 * * *$ & $(0.251)$ & $0.584 * * *$ & $(0.094)$ \\
\hline $\mathrm{SIZE}_{\mathrm{it}}$ & $1.082^{* * *}$ & $(0.276)$ & $0.804 * * *$ & $(0.046)$ \\
\hline $\mathrm{AGE}_{\mathrm{it}}$ & 0.052 & $(0.366)$ & 0.012 & $(0.051)$ \\
\hline $\mathrm{EDUC}_{\mathrm{it}}$ & $0.030 * * *$ & $(0.014)$ & $0.017 * * *$ & $(0.002)$ \\
\hline CONS & 2.698 & $(4.540)$ & -5.613 & $(0.304)$ \\
\hline Dependent variable: $R D Y E S_{i t+1}$ & & -0.013 & & -0.187 \\
\hline SUBSTITUTE_HAT $_{\text {it }}$ & -0.013 & $(0.230)$ & -0.187 & $(0.181)$ \\
\hline TECHAGE_HAT $_{i t}$ & $0.385^{* *}$ & $(0.152)$ & $0.664 * * *$ & $(0.126)$ \\
\hline RDYES $_{\text {it }}$ & $1.049 * * *$ & $(0.102)$ & $1.705^{* * *}$ & $(0.080)$ \\
\hline SALESDIF $_{\text {it }}$ & 0.085 & $(0.080)$ & $0.266 * * *$ & $(0.059)$ \\
\hline $\mathrm{SIZE}_{\mathrm{it}}$ & $0.201^{* * *}$ & $(0.039)$ & $0.198^{* * *}$ & (0.029) \\
\hline $\mathrm{AGE}_{\mathrm{it}}$ & -0.043 & $(0.061)$ & -0.055 & $(0.039)$ \\
\hline $\mathrm{EDUC}_{\mathrm{it}}$ & $0.010^{* *}$ & $(0.004)$ & $0.005^{* * *}$ & $(0.002)$ \\
\hline CONS & $-2.533^{* * *}$ & $(0.334)$ & $-1.632 * * *$ & $(0.159)$ \\
\hline MILLS (lambda) & 2.312 & $(2.376)$ & $1.984 * * *$ & $(0.179)$ \\
\hline No. of observations & \multicolumn{2}{|c|}{1,214} & \multicolumn{2}{|c|}{2,864} \\
\hline No. of censored observations & \multicolumn{2}{|c|}{733} & \multicolumn{2}{|c|}{1,674} \\
\hline No. of uncensored observations & \multicolumn{2}{|c|}{481} & \multicolumn{2}{|c|}{1,190} \\
\hline Wald chi ${ }^{2}$ & \multicolumn{2}{|c|}{138.94} & \multicolumn{2}{|c|}{$4,071.66$} \\
\hline Prob $>$ chi $^{2}$ & \multicolumn{2}{|c|}{0.000} & \multicolumn{2}{|c|}{0.000} \\
\hline
\end{tabular}

Note: bootstrapped standard errors in brackets (200 iterations); all estimations include 10 (Swiss sample) and 22 (German sample) industry dummies (partly significant). The estimation procedure is a twostep heckman procedure (stata software).

*, **, *** indicates a significant level of $90 \%, 95 \%$, and $99 \%$ respectively. 
Table A1: Instruments are not correlated with the dependent variables: estimation results of twostep heckman models

\begin{tabular}{|c|c|c|c|c|}
\hline & \multicolumn{2}{|c|}{ Switzerland } & \multicolumn{2}{|c|}{ Germany } \\
\hline & TECHAGE & SUBSTITUTE & TECHAGE & SUBSTITUTE \\
\hline \multicolumn{5}{|l|}{ Dependent variable: $L N R D E X P_{i t+1}$} \\
\hline \multirow{2}{*}{ TAXBURDEN $_{\mathrm{it}} /$ DOMINANCE $_{\mathrm{it}}$} & 0.069 & & 0.035 & \\
\hline & $(0.156)$ & & $(0.133)$ & \\
\hline \multirow[t]{2}{*}{$\mathrm{COPY}_{\text {it }} / \mathrm{SERVQUAL}_{\text {it }}$} & & 0.021 & & 0.068 \\
\hline & & $(0.115)$ & & $(0.085)$ \\
\hline \multirow[t]{2}{*}{$\operatorname{LNRDEXP}_{\text {it }}$} & 0.133 & $0.134^{*}$ & $0.473 * * *$ & $0.472 * * *$ \\
\hline & $(0.093)$ & $(0.080)$ & $(0.032)$ & $(0.030)$ \\
\hline \multirow[t]{2}{*}{ SALESDIF $_{\text {it }}$} & $0.566 * *$ & $0.559 * *$ & $0.589 * * *$ & $0.588 * * *$ \\
\hline & $(0.259)$ & $(0.275)$ & $(0.098)$ & $(0.105)$ \\
\hline \multirow[t]{2}{*}{$\mathrm{SIZE}_{\text {it }}$} & $1.007 * * *$ & $1.000 * * *$ & $0.719 * * *$ & $0.719 * * *$ \\
\hline & $(0.335)$ & $(0.298)$ & $(0.040)$ & $(0.038)$ \\
\hline \multirow[t]{2}{*}{$\mathrm{AGE}_{\mathrm{it}}$} & 0.024 & -0.029 & 0.020 & 0.022 \\
\hline & $(0.349)$ & $(0.323)$ & $(0.047)$ & 0.044 \\
\hline \multirow[t]{2}{*}{$\mathrm{EDUC}_{\mathrm{it}}$} & $0.033 * * *$ & $0.033 * * *$ & $0.019 * * *$ & $0.019 * * *$ \\
\hline & $(0.015)$ & $(0.013)$ & $(0.002)$ & $(0.002)$ \\
\hline \multirow[t]{2}{*}{ CONS } & 2.368 & 2.418 & $-5.215 * * *$ & $-5.263 * * *$ \\
\hline & $(4.698)$ & $(4.335)$ & $(0.285)$ & $(0.273)$ \\
\hline \multicolumn{5}{|l|}{ Dependent variable: $R D Y E S_{i t+1}$} \\
\hline \multirow[t]{2}{*}{ TAXBURDEN $_{\text {it }} /$ DOMINANCE $_{\text {it }}$} & 0.057 & & 0.014 & \\
\hline & $(0.039)$ & & $(0.106)$ & \\
\hline \multirow[t]{2}{*}{$\mathrm{COPY}_{\text {it }} / \mathrm{SERVQUAL}_{\mathrm{it}}$} & & 0.042 & & 0.026 \\
\hline & & $(0.034)$ & & $(0.065)$ \\
\hline \multirow[t]{2}{*}{ RDYES $_{\text {it }}$} & $1.151^{* * *}$ & $1.137 * * *$ & $1.846^{* * *}$ & $1.845^{* * *}$ \\
\hline & $(0.094)$ & $(0.090)$ & $(0.066)$ & $(0.070)$ \\
\hline \multirow[t]{2}{*}{ SALESDIF $_{\text {it }}$} & 0.077 & 0.061 & $0.276^{* * *}$ & $0.276 * * *$ \\
\hline & $(0.081)$ & $(0.094)$ & $(0.060)$ & $(0.056)$ \\
\hline \multirow[t]{2}{*}{$\mathrm{SIZE}_{\text {it }}$} & $0.213 * * *$ & $0.206 * * *$ & $0.166^{* * *}$ & $0.167 * * *$ \\
\hline & $(0.036)$ & $(0.036)$ & $(0.023)$ & $(0.021)$ \\
\hline \multirow[t]{2}{*}{$\mathrm{AGE}_{\text {it }}$} & -0.036 & -0.040 & $(-0.027$ & -0.027 \\
\hline & $(0.060)$ & $(0.064)$ & $(0.036)$ & 0.033 \\
\hline \multirow[t]{2}{*}{$\mathrm{EDUC}_{\mathrm{it}}$} & $0.010 * *$ & $0.010 * * *$ & $0.006^{* * *}$ & $0.006^{* * *}$ \\
\hline & $(0.003)$ & $(0.003)$ & $(0.002)$ & $(0.002)$ \\
\hline \multirow[t]{2}{*}{ CONS } & $-2.468 * * *$ & $-2.422 * * *$ & $-1.472 * * *$ & $-1488 * * *$ \\
\hline & $(0.320)$ & $(0.330)$ & $(0.156)$ & $(0.153)$ \\
\hline \multirow[t]{2}{*}{ MILLS (lambda) } & 2.541 & 2.591 & $1.914 * * *$ & $1.914^{* * *}$ \\
\hline & $(2.605)$ & $(2.402)$ & $(0.175)$ & $(0.172)$ \\
\hline No. of observations & 1,214 & 1,214 & 2,864 & 2,864 \\
\hline No. of censored observations & 733 & 733 & 1,674 & 1,674 \\
\hline No. of uncensored observations & 481 & 481 & 1,190 & 1,190 \\
\hline Wald chi ${ }^{2}$ & 108.35 & 98.34 & 3,933.85 & $3,666.83$ \\
\hline Prob $>$ chi $^{2}$ & 0.000 & 0.000 & 0.000 & 0.000 \\
\hline
\end{tabular}

Note: bootstrapped standard errors in brackets (200 iterations); all estimations include 10 (Swiss sample) and 22 (German sample) industry dummies (partly significant). The estimation procedure is a twostep heckman procedure (stata software).

$*$, **, *** indicates a significant level of $90 \%, 95 \%$, and $99 \%$ respectively. 
Table A2: Instruments are not correlated with the residuum: estimation results of OLS regressions

\begin{tabular}{|c|c|c|c|c|}
\hline & \multicolumn{2}{|c|}{ Switzerland } & \multicolumn{2}{|c|}{ Germany } \\
\hline & RESID_T & RESID_S & RESID_T & RESID_S \\
\hline \multirow{2}{*}{ TAXBURDEN $_{\text {it }} /$ DOMINANCE $_{\text {it }}$} & 0.246 & & -0.012 & \\
\hline & $(0.206)$ & & $(0.124)$ & \\
\hline \multirow[t]{2}{*}{$\mathrm{COPY}_{\mathrm{it}} / \mathrm{SERVQUAL}_{\mathrm{it}}$} & & 0.150 & & -0.013 \\
\hline & & $(0.187)$ & & $(0.080)$ \\
\hline \multirow[t]{2}{*}{$\operatorname{LNRDEXP}_{\text {it }}$} & $0.272 * * *$ & $0.268 * * *$ & $0.204 * * *$ & $0.204^{* * *}$ \\
\hline & $(0.029)$ & $(0.030)$ & $(0.017)$ & $(0.017)$ \\
\hline \multirow[t]{2}{*}{ SALESDIF $_{\text {it }}$} & 0.069 & 0.006 & -0.133 & -0.131 \\
\hline & $(0.467)$ & $(0.466)$ & $(0.086)$ & $(0.086)$ \\
\hline \multirow[t]{2}{*}{$\mathrm{SIZE}_{\mathrm{it}}$} & 0.312 & 0.276 & $-0.352 * * *$ & $-0.352 * * *$ \\
\hline & $(0.208)$ & $(0.204)$ & $(0.033)$ & $(0.033)$ \\
\hline \multirow[t]{2}{*}{$\mathrm{AGE}_{\mathrm{it}}$} & -0.098 & -0.115 & 0.003 & 0.001 \\
\hline & $(0.339)$ & $(0.339)$ & $(0.045)$ & $(0.045)$ \\
\hline \multirow[t]{2}{*}{ EDUC $_{i t}$} & $0.033^{*}$ & $0.032 *$ & $-0.007^{* * *}$ & $-0.007 * * *$ \\
\hline & $(0.019)$ & $(0.019)$ & $(0.002)$ & $(0.002)$ \\
\hline \multirow[t]{2}{*}{ CONS } & $-12.855^{* * *}$ & $-12.473 * * *$ & $1.847 * * *$ & $1.858 * * *$ \\
\hline & $(1.545)$ & $(1.473)$ & $(0.274)$ & $(0.275)$ \\
\hline No. of observations & 1,214 & 1,214 & 2,864 & 2,864 \\
\hline$F(16,1197) / F(28,2835)$ & 21.88 & 21.74 & 7.99 & 8.00 \\
\hline Prob $>$ chi $^{2}$ & 0.000 & 0.000 & 0.000 & 0.000 \\
\hline
\end{tabular}

Note: OLS estimation with heteroscedasticity robust standard errors.

$*, * *, * * *$ indicates a significant level of $90 \%, 95 \%$, and $99 \%$ respectively. 